\title{
Springtime warming and biomass burning causing ozone episodes in South and Southwest China
}

\author{
Y. C. Lee ${ }^{1} \cdot$ K. L. Chan ${ }^{1} \cdot$ M. O. Wenig ${ }^{1}$ \\ Received: 4 February 2019 / Accepted: 13 May 2019 \\ (C) Springer Nature B.V. 2019
}

\begin{abstract}
A detailed analysis of springtime ozone outbreaks in South/Southwest China is presented in this paper, providing an insight into a regional photochemical and climate problem. A major ozone episode in 2013 was the first ever in April and the worst in Hong Kong up to 2018, measuring a peak ozone concentration of $293 \mu \mathrm{g} \mathrm{m}^{-3}$. This multi-day, ozone pollution was evidenced by similar conditions in the Pearl River Delta (PRD), and an even more severe episode in Kunming (Yunnan) in Southwest China. Concurrently, widespread air temperature composite anomalies of up to about $+4^{\circ} \mathrm{K}$ were observed in the region, particularly during $6 \mathrm{Z}$ (14:00 local time). The global annual geopotential height anomaly implied increased atmospheric stability and inhibited dispersion - consistent with global warming impacts for the region. Backward trajectories, satellite observations, and transport model simulations characterized the biomass burning sources. Results indicated that activities in Indochina, South and Southwest China, and Africa were the main sources in South China while those in Burma dominated Southwest China. The close succession of outbreaks from west to east (Kunming, Guangzhou, and Hong Kong) suggests an eastward transport of ozone and precursors.
\end{abstract}

Keywords Springtime ozone $\cdot$ Biomass burning $\cdot$ Temperature anomaly $\cdot$ Geopotential height anomaly $\cdot$ South China $\cdot$ Southwest China

\section{Introduction}

Ozone $\left(\mathrm{O}_{3}\right)$ causes a variety of health effects and damage to ecosystems. A key component in photochemical smog formed by chemical reactions between oxides of nitrogen $\left(\mathrm{NO}_{x}\right)$ and volatile organic compounds (VOC), it is one of the primary greenhouse gases in the Earth's atmosphere (IPCC 2013), along with water vapor $\left(\mathrm{H}_{2} \mathrm{O}\right)$, carbon dioxide $\left(\mathrm{CO}_{2}\right)$, nitrous oxide $\left(\mathrm{N}_{2} \mathrm{O}\right)$, and methane $\left(\mathrm{CH}_{4}\right)$. At low latitudes such as in South China, photochemistry is the dominant source of tropospheric ozone whereas stratospheric input of ozone mainly takes place in the middle to high latitudes, especially in early spring (Collins et al. 2003). Despite the huge problem posed

Electronic supplementary material The online version of this article (https://doi.org/10.1007/s11869-019-00709-5) contains supplementary material, which is available to authorized users.

K. L. Chan

lok.chan@1mu.de

1 Meteorological Institute, Ludwig-Maximilians-Universität München, Munich, Germany by tropospheric ozone, there is, however, one positive side of it - the photochemical reactions of $\mathrm{O}_{3}$ lead to the production of hydroxyl $(\mathrm{OH})$ radicals, which remove major greenhouse gases like methane $\left(\mathrm{CH}_{4}\right)$ from the atmosphere.

Ozone concentrations vary hugely over the globe, in space and time, on seasonal, interannual, and decadal timescales. A major problem is found in hotspots over or near metropolitan areas where high ozone levels usually occur during the summer. The situation may be particularly serious when low winds and stagnating atmospheres prevail, leading to ozone buildup. Regarding year-to-year trends, an increase was found in South China for the typical ozone season of July to September (Lee et al. 2013). While ozone exceedances were regularly reported for summer, episodic ozone concentration for autumn was reported for the first time in 2000 in Hong Kong as anticipated from the positive relationship between ozone and temperature (Bloomer et al. 2009). In this paper, we focus on episodes during springtime, which displays the highest warming rate after winter (Chan et al. 2012).

In the Pearl River Delta (PRD) (Fig. 1a) of China, the annual average ozone concentration in 2014 was reported to have increased by 19\% compared with that of 2006 (Hong Kong Government 2015). All monitoring stations in the 

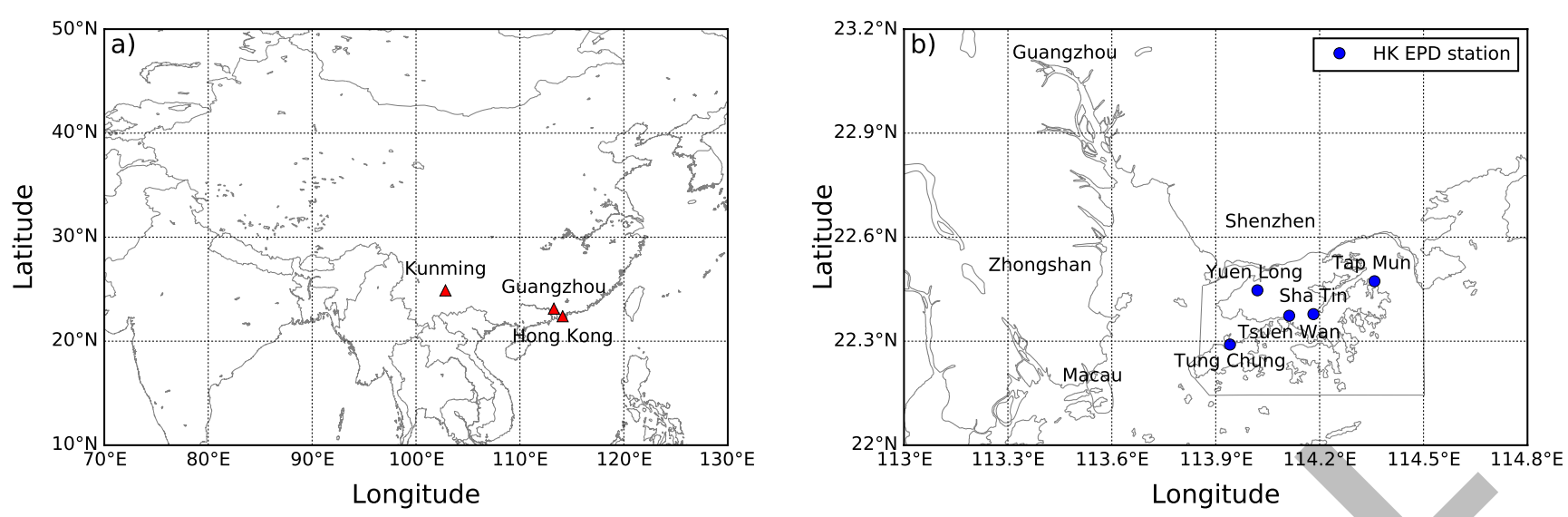

c) PRD surface temperature

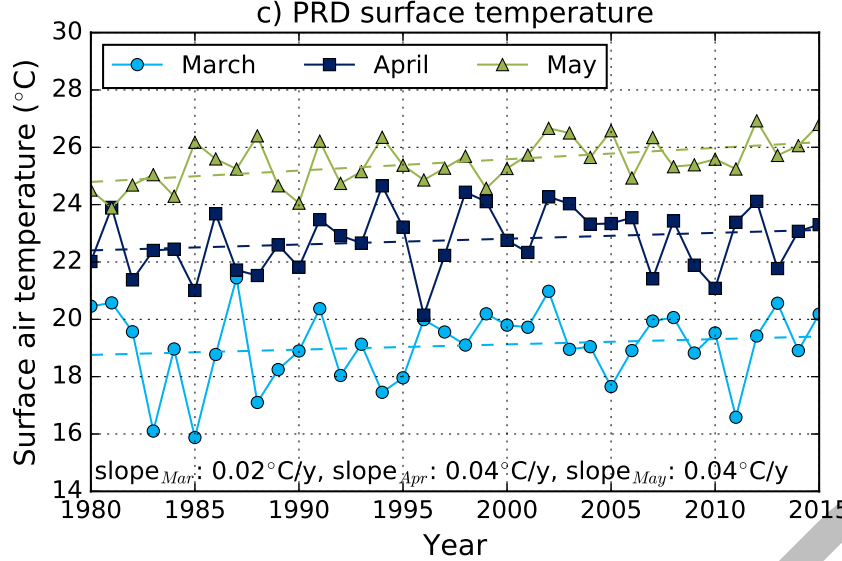

d) Hong Kong $\mathrm{O}_{3}$ concentration

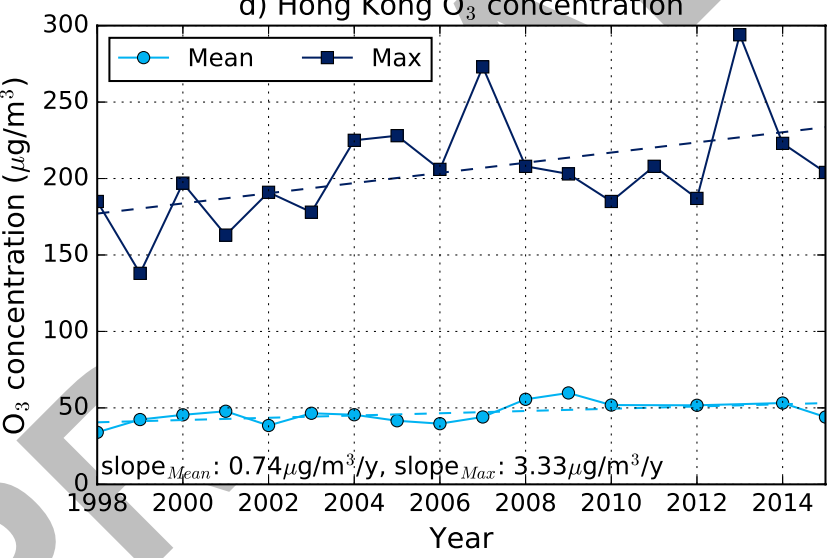

e) PRD $\mathrm{O}_{3}$ concentration
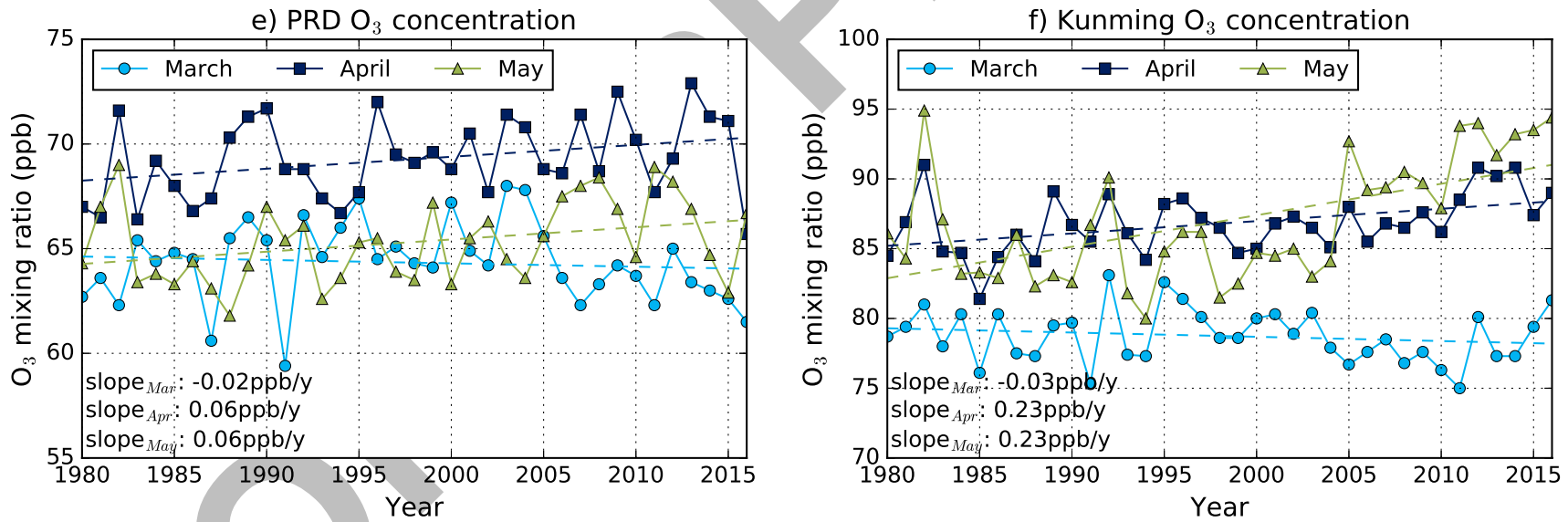

Fig. 1 a Locations of Hong Kong, Guangzhou, and Kunming. b EPD ambient air monitoring stations. c Air temperature in the Pearl River Delta (PRD). d Springtime ozone in Hong Kong (mean, maximum). Monthly mean ozone mixing ratio in e PRD. f Kunming (Southwest China)

region, in fact, recorded significant exceedance of the Chinese national hourly limits $\left(200 \mu \mathrm{g} \mathrm{m}^{-3}, 160 \mu \mathrm{g} \mathrm{m}^{-3}\right.$ class 2 and 1$)$ in 2014. As a comparison, the USEPA $8 \mathrm{~h}$ standard is $137 \mu \mathrm{g} /$ $\mathrm{m}^{3}(70 \mathrm{ppb})$, which is the annual fourth highest daily maximum $8 \mathrm{~h}$ concentration, averaged over 3 years (USEPA 2016). Hong Kong's $8 \mathrm{~h}$ limit is $160 \mu \mathrm{g} \mathrm{m}^{-3}$. In South China, ozone had increased so much that it had overtaken $\mathrm{PM}_{2.5}$ to become the air pollutant of most concern (Guangdong Provincial Environmental Monitoring Centre GPEMC 2014, 2015). Springtime impacts of Southeast Asia on ozone over
Taiwan, for instance, were reported by Chan and Chan (2017). Ozone-rich air masses from biomass burning of tropical forests had been shown by Chan et al. (2003a, 2003b) to pass through the Indo-Burma region in spring and resulted in elevated ozone levels in Hong Kong. Lee et al. (2013) reported on biomass burning contributing to local black carbon levels in spring, identifying Indochina/Southwest China as the main contributor. Among the non-methane volatile organic compound (NMVOCs), $\mathrm{CO}$ and $\mathrm{NO}_{x}$ emissions, $\mathrm{CO}$ is considered an excellent signature for biomass burning 
emissions. Atmospheric CO has a lifetime of about 6 days (National Aeronautics and Space Administration, NASA 2017), or 0.2 months (NASA n.d.-a) to around 2 months (Petrenko et al. 2013) compared with the inter-hemispheric mixing time of 1-2 years (NASA n.d.-b). It is not well mixed in the atmosphere and is therefore a useful tracer for combustion sources.

In this paper, we present an in depth analysis of springtime regional ozone episodes in Hong Kong, and South and Southwest China (Fig. 1) in April 2013, in the wake of rapid temperature rise in winter and spring (Chan et al. 2012) over the past decades. Satellite CO, aerosol characteristics, and backward trajectories provide complementary information on locating possible source regions. Contributing sources were determined for GEOS-Chem model simulations. Air temperature $(\mathrm{K})$ composite anomalies were analyzed to characterize the warming effects, together with an examination of related meteorological factors. As the biomass burning activities during May involve multiple regions in Central and North China, we focus mainly on March and April. The worst springtime outbreak before 2018 occurred in April 2013, apparently linked to extreme weather and intense burning activities.

\section{Data and methods}

\section{In situ monitoring data}

Surface pollutant data including ozone, $\mathrm{CO}, \mathrm{NO}_{x}$, and particulate matter $\left(\mathrm{PM}_{10}, \mathrm{PM}_{2.5}\right)$ were acquired from the Environmental Protection Department (EPD) of the Hong Kong Special Administrative Region (HKSAR). Point measurements were made by continuous automatic equipment in monitoring stations, including the $\mathrm{NO}, \mathrm{NO}_{2}, \mathrm{NO}_{x}$ chemiluminescence analyzer, $\mathrm{O}_{3} \mathrm{UV}$ absorption analyzer, $\mathrm{CO}$ nondispersive infrared absorption analyzer with gas filter correlation, adhering to monitoring and data quality assurance practices (Hong Kong Government 2015). Quality control procedures, patterned on the USEPA QA/QC procedures (USEPA 2017), were adopted. Location of the stations and period of data available were taken into account in the selection of stations. Data from the urban ambient monitoring sites of Sha Tin, Tung Chung, Tsuen Wan, and Yuen Long were representative of the territory of Hong Kong and used (Fig. 1b). Background and roadside stations were not included.

\section{Satellite observations}

Owing to the sparse nature of measurement data from mainland China, interannual time series of monthly springtime surface air temperature of (a) the PRD Region and (b) Southwest China (Kunming) were retrieved and processed on the NASA Goddard Earth Sciences Data and Information Services Center (GES DISC)'s Geospatial Interactive Online Visualization ANd aNalysis Infrastructure (Giovanni 4) interface. The time series were based on the Modern Era Retrospectiveanalysis for Research and Applications (MERRA) data, a NASA reanalysis product for the satellite era, which were generated using version 5.2.0 of the Goddard Earth Observing System (GEOS) (Suarez et al., (2005) atmospheric model and data assimilation system (DAS). Gelaro et al. (2017) provide an overview of MERRA-2. NASA's Global Modeling and Assimilation Office (GMAO) undertook MERRA with a purpose to place observations from NASA's Earth Observing System satellites into a climate context (National Center for Atmospheric Research, NCAR). However, this data set has limitations. The model and analysis resolution are each at $1 / 2 \times 2 / 3^{\circ}$, and the product suite includes only monthly diurnal files, covering the modern satellite era from 1979 to the present. The interannual time series of monthly ozone mixing ratio were similarly acquired. For Kunming, about $1900 \mathrm{~m}$ above sea level, a vertical slice number of $772 \mathrm{hPa}$ was used. Moderate Resolution Imaging Spectroradiometer (MODIS), Fire Radiative Power (FRP) (Justice et al. 2002) (Supporting material S1, but no longer on Giovanni 4), and Aerosol Small Mode Fraction (S2) data were used to illustrate the biomass burning areas and the fine particulates generated. FRP, as the daily average in $\left(\mathrm{mW} / \mathrm{m}^{2}\right)$, is the thermal radiation from burning vegetation and open fires as measured by a remote sensing system, including MODIS sensors. The FIRMS fire maps (Fire Information for Resource Management System, see Giglio et al. 2016) can be conveniently used. The data for ozone total column, total column $\mathrm{CO}$, air temperature at surface, as well as cloud fraction (daytime, ascending) were retrieved from Giovanni 4 , based on global $1.0^{\circ} \times 1.0^{\circ}$ daily level 3 products from the atmospheric infrared sounder (AIRS) on board the Aqua satellite. Time-averaged hourly map of incident shortwave radiation (comprising UV) on land at $6 Z$ was based on MERRA-2 data.

To show surface ozone distributions, statistical correlations, comprising linear regression of total column ozone and surface air temperature, were computed for each grid on Giovanni 4. Correlation occurs at a temperatures of $20^{\circ} \mathrm{C}$ or more (Lollar et al. 2004) on the earth's surface. As regards the ozone layer in the stratosphere, the maximum temperature is $-2.5^{\circ} \mathrm{C}$ at $50 \mathrm{~km}$, which is too low for correlations. On the other hand, compilation of maps of tropospheric column ozone based on the OMI and microwave limb sounder (MLS) (Ziemke et al. 2006) was not available on Giovanni 4. Statistical correlations were therefore used as gross indication, mainly on land. 


\section{Meteorological data}

Wind fields, anomalies for geopotential height, air temperature, and maximum/mean temperature were generated for specific days/month $(1000,925 \mathrm{hPa})$ for the period $2013-$ 2015, based on composites (mean) of the National Centers for Environmental Prediction (NCEP/NCAR)'s reanalysis data. Evaluation of the temperature data helped to characterize air temperature changes. To understand the diurnal differences, sub-daily maps were plotted, with 6-hourly composites from NCEP/NCAR reanalysis data. The Interactive Plotting and Analysis tool of the Earth System Research Laboratory of National Oceanic and Atmospheric Administration (NOAA) was used. Climate normals, threedecade averages of climatological variables produced once every 10 years, were updated from 1958-1996 to 19812010 by NOAA. Temperature data for Hong Kong were obtained from the Hong Kong Observatory (HKO) website www.hko.gov.hk. For the vertical distribution of pressure, temperature, wind speed of the atmospheric column, a tephigram was generated for the episode day on the Hong Kong University of Science and Technology's (HKUST) Real-time Display at http://envf.ust.hk/.

\section{Model simulations}

The GEOS-Chem chemical transport model (CTM) was used to simulate the transport of major anthropogenic air pollutants, in our case $\mathrm{CO}$, as the signature of biomass burning. This model is a global three-dimensional chemistry transport model driven by assimilated meteorological fields from the Goddard Earth Observing System (GEOS) of the NASA GMAO (Bey et al. 2001). In the current study, the GEOS5FP meteorological data regridded with a horizontal resolution of $2.0^{\circ}$ (latitude) $\times 2.5^{\circ}$ (longitude), a vertical resolution of 72 hybrid pressure-sigma levels, and a temporal resolution of $1 \mathrm{~h}$ was used to drive GEOS-Chem version 10-01. In total, there are 92 tracers included in the Universal troposphericstratospheric Chemistry eXtension (UCX) simulations (Eastham et al. 2014). Transportation of atmospheric components was calculated every $15 \mathrm{~min}$ in the model with both emission and chemistry time step of $30 \mathrm{~min}$. In the study, a multiple emissions approach was used to identify the source origins of anthropogenic pollutants. Their contribution from the regions of interest was estimated by taking the difference between the standard simulation (all the emissions included) and simulations with biomass burning emissions from specific regions switched off (Chan and Chan 2017). Satellite observations of ozone vertical column were converted to surface concentrations by dividing the satellite ozone column by the modeled column and the ratio was then multiplied by the modeled surface ozone concentration.
The emission inputs were taken from external emission inventories. In this study, the anthropogenic emissions were taken from the Emission Database for Global Atmospheric Research (EDGAR) version 4.2 (EDGAR4.2 2011), while overridden with some regional inventories where available. A mosaic Asian anthropogenic emission inventory for the MICS-Asia and the HTAP projects (MIX) inventory ( $\mathrm{Li}$ et al. 2017) was used in the simulation as anthropogenic emission database over Asia. The emissions of carbonaceous aerosols related to fossil fuel and biofuel combustion were taken from a global emissions inventory introduced by Bond et al. (2007) while the biomass burning emissions were derived from the Global Fire Emissions Database version 4 (GFED4) monthly data (Giglio et al. 2013). The Model of Emissions of Gases and Aerosols from Nature (MEGAN) emission inventory version 2.1 was used to account for biogenic emissions in the simulations (Guenther et al. 2012). Volcanic emissions were taken from the Aerosol Comparisons between Observations and Models (AeroCOM) database (Diehl et al. 2012). In this study, the simulations were carried out from January 2014 to December 2014 with 3 months (October to December 2013) of spin up prior to the simulations.

The HYSPLIT (HYbrid Single Particle Lagrangian Integrated Trajectory) model of NOAA was used to compute air parcel backward trajectories and determines the origin of air masses, thereby assigning possible pollutant source areas. Backward trajectories to Hong Kong and Kunming at 00 UTC or other specified hour were calculated for altitudes up to $6 \mathrm{~km}$ or more at different heights above ground level. Intervals of $500 \mathrm{~m}$ were conveniently used in the study. Travel time is for a specified length of time in hourly steps, up to180/260 h duration in the current study. Vertical motion was provided by the meteorological model's vertical velocity fields. The NCEP Global Data Assimilation System (GDAS) data was used as model input. Stein et al. (2015) is referred to for more details about HYSPLIT.

\section{Results and discussions}

\section{A climate warming-induced situation: warming springs}

According to an estimate for the last 45 years, global surface temperature rose at an average rate of about $0.17^{\circ} \mathrm{C}$ per decade-more than twice as fast as the $0.07{ }^{\circ} \mathrm{C}$ per decade observed for the entire period of recorded observations (18802015) (NOAA 2017a). This is evidently linked to increased anthropogenic activities which release excessive greenhouse gases. Warming is widespread and is greatest at higher northern latitudes - in winter and spring (IPCC 2013). Not surprisingly, there has been a shift in the timing of the seasons. Spring 
arrives earlier than usual and gets ever longer, and winters are shorter. The gradual shift is well observed. Despite temporal and spatial variability, an increasing trend is observed in the maximum, mean, and minimum temperatures in spring in Hong Kong. They are statistically tested to be significant at the $5 \%$ level for all four seasons, based on well over a hundred years' data (1885-2010) (Chan et al. 2012).

Temperature increases are seen in the PRD Region (Fig. $1 \mathrm{a}-\mathrm{c})$, as shown by the interannual time series of monthly surface air temperature from MERRA, during the springs of 1980-2015, spanning a period of over 30 years. Clear signs of warming are found in the records. For the last 30 years, each decade has been warmer than the one before. It comes as no surprise that a small $p$ value $(0.002$, i.e., $<0.01)$ and a high level of significance for the trend is observed for May. However, matters turn out contrary to expectations for March and April for the PRD. The corresponding $p$ values in these 2 months for Kunming yield a level of significance of just greater than 0.1 , suggesting a high probability of variation due to random chance, though temperature increases are mostly visible. Temperature increases are, however, broadly consistent with global trends, with the understanding that changes before 1980 occurred at much slower rates.

\section{The springtime ozone trend in the region: 1980 to 2016}

Though sometimes it is difficult to discern definitive trends, trend lines help with interpreting the direction of data. An examination of the results reveals that springtime ozone concentrations in Hong Kong followed a prominent upward trend, as presented in Fig. 1d (Sha Tin) from 1998 to 2015, albeit at a lower pace than in autumn, and data was scanty. Their statistical significance was demonstrated by $p$ values at $<0.05(0.02,0.038$ for mean, maximum, 95\% confidence). On the other hand, the MERRA time series (1980 to 2016) for the PRD region in Fig. 1e had a seemingly positive trend for April and May with fluctuations (however, May has lower ozone due to sharply reduced biomass burning activities), but it turned out that the $p$ value for April $(<0.1)$ demonstrated significance at $90 \%$ confidence only, against expectations. As for Kunming, the increasing MERRA trend, by contrast, was highly conspicuous (Fig. 1f) with a very significant $p$ value of $\ll 0.001(0.0002)$ for May and a highly significant 0.01 for April. This disclosed a growing problem in Southwest China, despite comparable temperature and higher altitudes. As yet there was insufficient data coverage, monitoring data in particular, especially for Hong Kong. Like the temperature trends, most ozone data are subject to some uncertainty and are not enough for strong inferences to be drawn.

\section{Regional ozone outbreaks in spring}

Generally speaking, ozone episodes in China are severe and usually multi-day events (Ding et al. 2004). The worst springtime (April) episode up to 2018 occurred over several days in the region, mainly on 15 April 2013 in Hong Kong, with ozone concentrations exceeding the daily threshold. This was the first ever local episode for April. An earlier springtime event was recorded on 13 May 2007. The ozone episodes analyzed in this study occurred under typical meteorological conditions of high temperatures and high levels of solar radiation with widespread stagnant areas. And it was not limited to Hong Kong, but was urban and region wide, occurring across South/Southwest China. During the local episode, pollution levels hit nearly decade-level highs. An hourly high of $293 \mu \mathrm{g} \mathrm{m}^{-3}$ was observed on 15 April at Sha Tin, followed by $263 \mu \mathrm{g} \mathrm{m}^{-3}$ at Tap Mun and $262 \mu \mathrm{g} \mathrm{m}^{-3}$ at Tung Chung (S3). All the ozone concentrations in these stations exceeded the 1-h standard of $240 \mu \mathrm{g} \mathrm{m}^{-3}$ photochemical oxidants (as ozone) in use before 2014. Particulates originate from a wide range of sources as can be seen in EPD data on their website. The maximum hourly $\mathrm{PM}_{10}$ and $\mathrm{PM}_{2.5}$ (14th, 15th) were $234 \mu \mathrm{g} \mathrm{m}^{-3}$ and $158 \mu \mathrm{g} \mathrm{m}^{-3}$. These are shown in $\mathrm{S} 3$ for 3 days from 14 th. The maximum temperatures on 14 th $/ 15$ th were 24.3 and $27.1^{\circ} \mathrm{C}$ respectively (Lollar et al. 2004). Two other milder springtime episodes in Hong Kong were observed on 27 April 2014 and 24 April 2015, with maximum hourly ozone concentrations of $276 \mu \mathrm{g} \mathrm{m}^{-3}$ and $245.6 \mu \mathrm{g} \mathrm{m}^{-3}$, and a maximum temperature of $29^{\circ} \mathrm{C}$ on both days.

Ozone pollution is worse in mainland China when compared with Hong Kong. In Guangzhou, the second highest ozone concentration of $565 \mu \mathrm{g} \mathrm{m}^{-3}$ (288 Dobson units, DU, daily) for the month was coincidentally recorded on 14 April 2016, 1 day before the Hong Kong recordings. Satellite units are used because archived data were not available for mainland cities. Satellite observations of ozone column in Dobson unit can be converted to volume mixing ratio based on GEOSChem simulation of ozone vertical profile and the fact that $1 \mathrm{DU}$ is equivalent to $2.69 \times 10^{20}$ ozone molecules per square meter (NASA 2013).

Kunming in Southwest China saw a steeper ozone trend than the PRD in April and May. In this mountainous region, a spatial variability in concentration due to topography is likely. The rugged terrain was, however, found to be conducive to the accumulation of ozone (Anttila et al. 2016). Kunming largely suffered from a surge in pollution far exceeding limits. The ozone concentration reached $628 \mu^{-3} \mathrm{~m}^{-3}$ (320 DU, daily) while the temperature rose to $23{ }^{\circ} \mathrm{C}$ on 13 April. In recent years, the worsening pollution resulted in Kunming's trailing in air quality (China National Environmental Monitoring Centre 2016). The area-averaged ozone total column data indicated that the second highest ozone in Kunming was measured around 12/13 April 2013, i.e., 2 to 3 days earlier than in 
Hong Kong. This succession of the episodes in Kunming, Guangzhou, and Hong Kong from 12 to 15 April suggests that the episodes may have common upwind sources.

\section{Sources of ozone precursors in spring and their contributions}

Spring and winter are the favorable seasons for biomass burning in the Northern Hemisphere including the sub-Saharan region, the Arabian Peninsula, northern India, Indochina, Indonesia, and Eastern China, producing large amounts of emissions that are necessary precursors of ozone. The Southeast Asian region is active in spring, as proven by a seasonal distribution of pixel counts for the major biomass burning regions (Lee et al. 2013). For burning sources, NASA's readily accessible daily FIRMS fire maps can be conveniently referred to at any time. Near real-time active fire data within 3 hours of satellite overpass were generated. With their help, the impact of northern South China on the southern part on the 15th was affirmed. This is additionally supported by backward trajectories coupled with data on 15 April, as
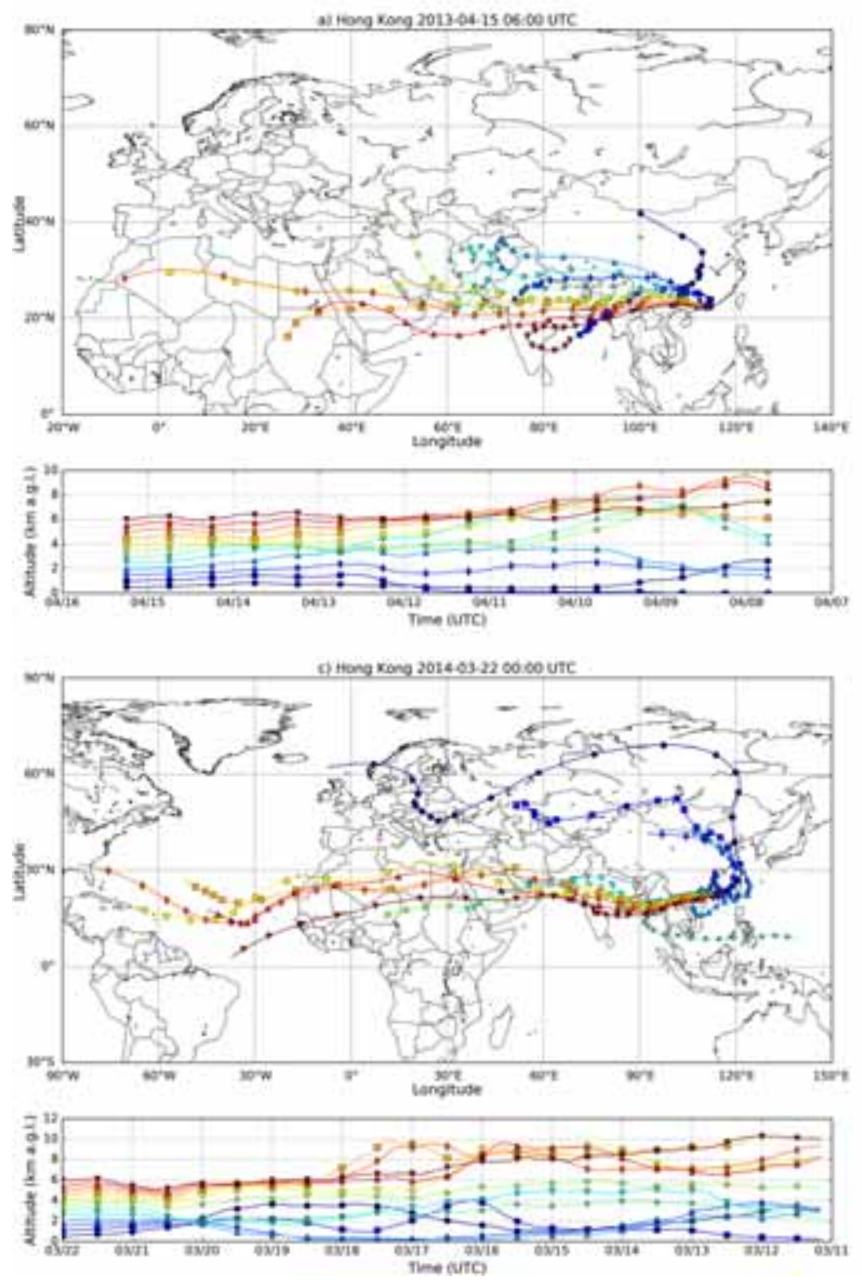

Fig. 2 Backward trajectories a on 15 April 2013 to Hong Kong. b Enlarged view of (a), on 22 March 2014 (c) to Kunming (d) shown in Fig. 2a, b, where a distinct low level monsoon wind arrived in Hong Kong and Guangzhou from North China/ Mongolia at a level of about $500 \mathrm{~m}$. The Sahara influence (Lee et al. 2012) on 22 March 2014 is shown for information in Fig. 2c. Subsequently, biomass burning almost disappeared entirely from South China on the 16th. The absence of monsoon influence from Kunming was anticipated because it was outside the realm of the northeast monsoon (Fig. 2d). On the other hand, the influence from Central and North China became insignificant when the southward bound winter monsoon weakened in April. Biomass burning in South China itself reached a peak in February, i.e., earlier than in Indochina. Its influence continued into March, but was significantly reduced in April (Lee et al. 2013). Biomass burning in Indochina/Southwest China can alternatively be inferred from images of MODIS FRP for April 2013 (S1) but it is no longer available on Giovanni 4.

With the help of the transport model, the individual impact of biomass burning sources on the regions was investigated and quantified. To this aim, biomass burning contributions from (i) Africa, (ii) Burma, (iii) India, (iv) Thailand,
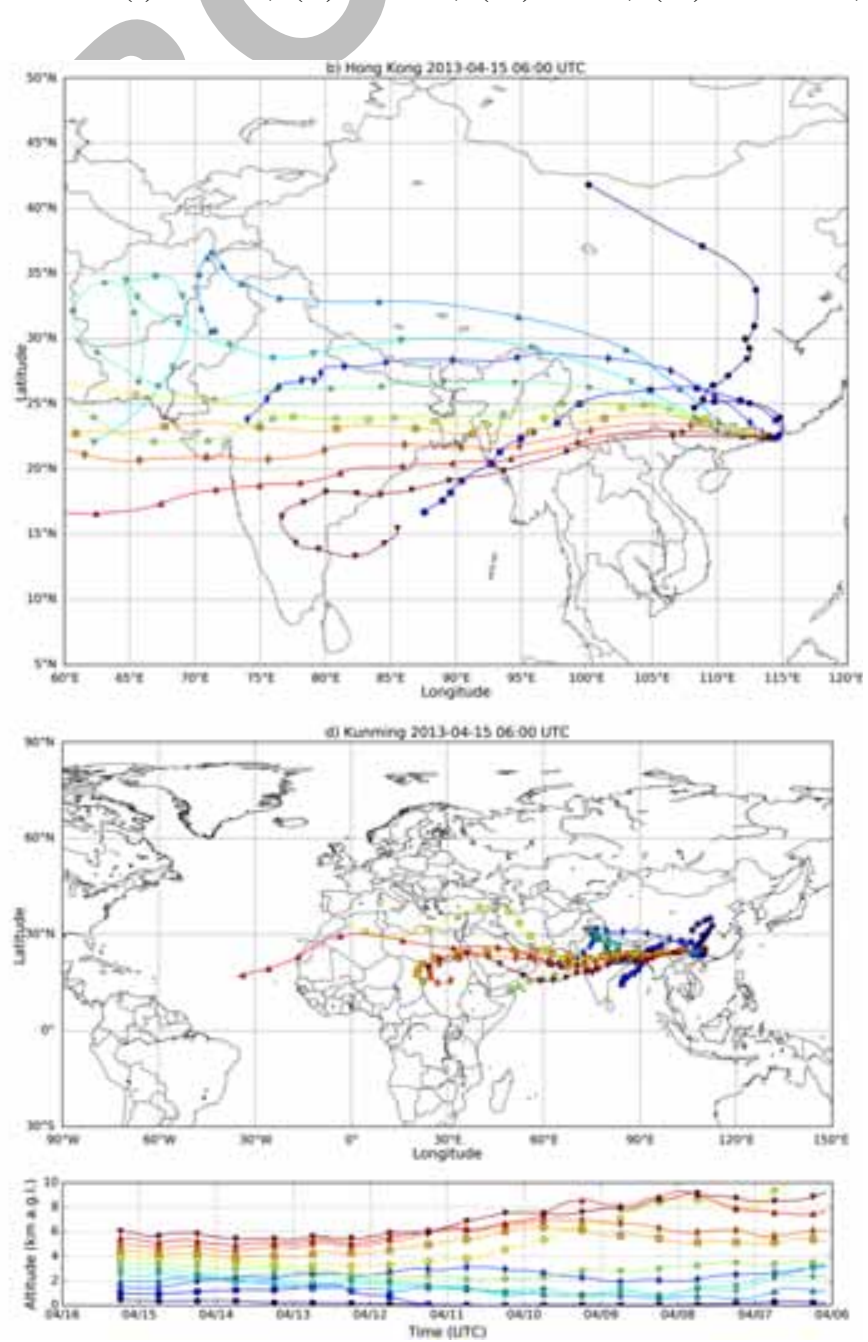
Vietnam, Laos (i.e., without Burma), (v) South/Central/North China (in fact Central and North China reaches their peak activity in summer), and (vi) Southwest China (locations in Fig. 3) were estimated by taking the differences between GEOS-Chem simulations with and without biomass burning sources in each region. This approach involved simulations based on source regions whose geographical boundaries are well defined. The magnitude of total column CO $\left(10^{18} \mathrm{molec} / \mathrm{cm}^{2}\right)$ is similar to Té et al.'s (2016) work which combined GEOS-Chem analyzes with satellite and surface measurements for Europe and the Southern hemisphere. Conversion of satellite-measured ozone column to surface concentrations used simple vertical distribution profiles simulated by GEOS-Chem. The surface ozone concentrations obtained are comparable with ground data. Therefore, we are confident that the surface concentration results are reliable.

The GEOS-Chem model seeks to reasonably reproduce daily column $\mathrm{CO}$ concentrations and allows interpretation to be made of the episode days, as well as the March and April concentrations, a summary of which are presented in Fig. 3a-c, based on relative contributions by the individual sources. Results for the episode day of 15 April 2013 explicitly demonstrate that Indochina (with Burma) contributed substantially to $\mathrm{CO}$ in Hong Kong, followed surprisingly by Africa and Southwest China, though the latter's impact had diminished in March and April. The maximum contributions from Indochina were calculated to be $0.14 \times 10^{18} \mathrm{molec} / \mathrm{cm}^{2} \mathrm{CO}$ on $15 \mathrm{April}$, in terms of total column CO. There was also influence from South China itself, as could be proved by the FIRMS fire maps. Influence from India, however, remained minimal.

In Kunming of Southwest China, $\mathrm{CO}$ has been ascribed to long-range transport of biomass burning aerosols from Burma, and in particular, from North Burma (Zhu et al. 2016), owing to Kunming's proximity to the source. A comparatively smaller influence arose from the rest of Indochina. Earlier, Chan et al. (2003a, b) observed frequent ozone enhancements in the lower troposphere of Kunming and Hong Kong, which has been put down to Southeast Asian biomass burning emissions. Biomass burning aerosols were later reported by Zhu et al. (2016) to be lifted upward to $5 \mathrm{~km}$ in Burma before transport to southwest China by strong westerly winds which typically flow across the mid-latitudes. The estimated total column $\mathrm{CO}$ contribution to Kunming by Burma was $0.21 \times 10^{18}$ molec $/ \mathrm{cm}^{2}$ on 15 April. During Kunming's own episode days around 12-13 April, total column CO would certainly be higher. After Burma (Fig. 3), came the contributions from Southwest China itself and the sub-Sahara region, with a very small input from India. The African biomass burning is in fact more intense in winter than in spring (Lee et al. 2013).

\section{Climatic and meteorological anomalies during the episode period}

\section{Temperature anomalies}

Fundamental to the ozone problem is the crucial effect of air temperature which is presented here as air temperature composite anomalies (K). Featured in Fig. $4 \mathrm{a}-\mathrm{c}$ for different times of the day on 15 April 2013, a conversion of $Z$ or Coordinated Universal Time (UTC) to local time entails an offset of $+8 \mathrm{~h}$. Temperature anomaly is a departure from a long-term average which is typically computed by averaging 30 or more years of temperature data (NOAA 2017b). A positive anomaly indicates that the observed temperature is warmer than the reference value while a negative anomaly indicates a cooler temperature. The association of anomalies with a reference value normalizes the data, allowing comparisons to be made. Comparisons can, for instance, be made on a month by month basis, in a way in which specific months cannot. Indeed, anomalies more accurately describe climate variability over large areas than absolute temperatures do.

Pronounced anomaly patterns engulf the region during the episode day, with marked temporal and spatial changes. The positive temperature anomaly at $1000 \mathrm{hPa}$ is observed in Fig. 4a to be extending southward from north China on 15 April 2013 0Z (8 am local time), reaching South China at $6 \mathrm{Z}(2 \mathrm{pm})$ when temperature-driven photochemical reactions invariably peaked, causing excessive ozone to be formed (Fig. 4b). Most of South China became very warm in the early afternoon, with a temperature anomaly of about $+4^{\circ} \mathrm{K}$. By that time, the anomaly covering Indochina at $0 \mathrm{Z}$ (Fig. 4a) had receded. However, the enhanced temperature reaching about $3^{\circ} \mathrm{K}$ anomaly shown in Fig. 4a for Indochina had accelerated the ozone formation, which was subsequently transported downwind. Region-wide, a strong positive anomaly dominated most of China in the daylight hours. Figure $4 \mathrm{c}$ shows anomaly from 6 to $12 \mathrm{Z}$ as daylight dimmed and dusk set in.

As a matter of fact, the greatest temperature anomaly during the episode day was found (Fig. 4b) in Central China, which traversed northwestward to North China, with an anomaly as high as over $+8^{\circ} \mathrm{K}$. A 2 m maximum air temperature $(\mathrm{K})$ composite anomaly is found for $6 \mathrm{Z}$ (not shown). However, this region was far away from the main biomass burning plume. The temperature composite mean at $6 \mathrm{Z}$ in Fig. $4 \mathrm{~d}$ shows that the mean temperature in Hong Kong was about $300^{\circ} \mathrm{K}$ or $27^{\circ} \mathrm{C}$, which was similar to that recorded, whereas that of Kunming was $305^{\circ} \mathrm{K}$ or $32{ }^{\circ} \mathrm{C}$. Country-wide, an increase of $0.9 \sim 1.5{ }^{\circ} \mathrm{C}$, which was larger than the global average, was reported for China's annual average during the past century (Ministry of Science and Technology 2015). 


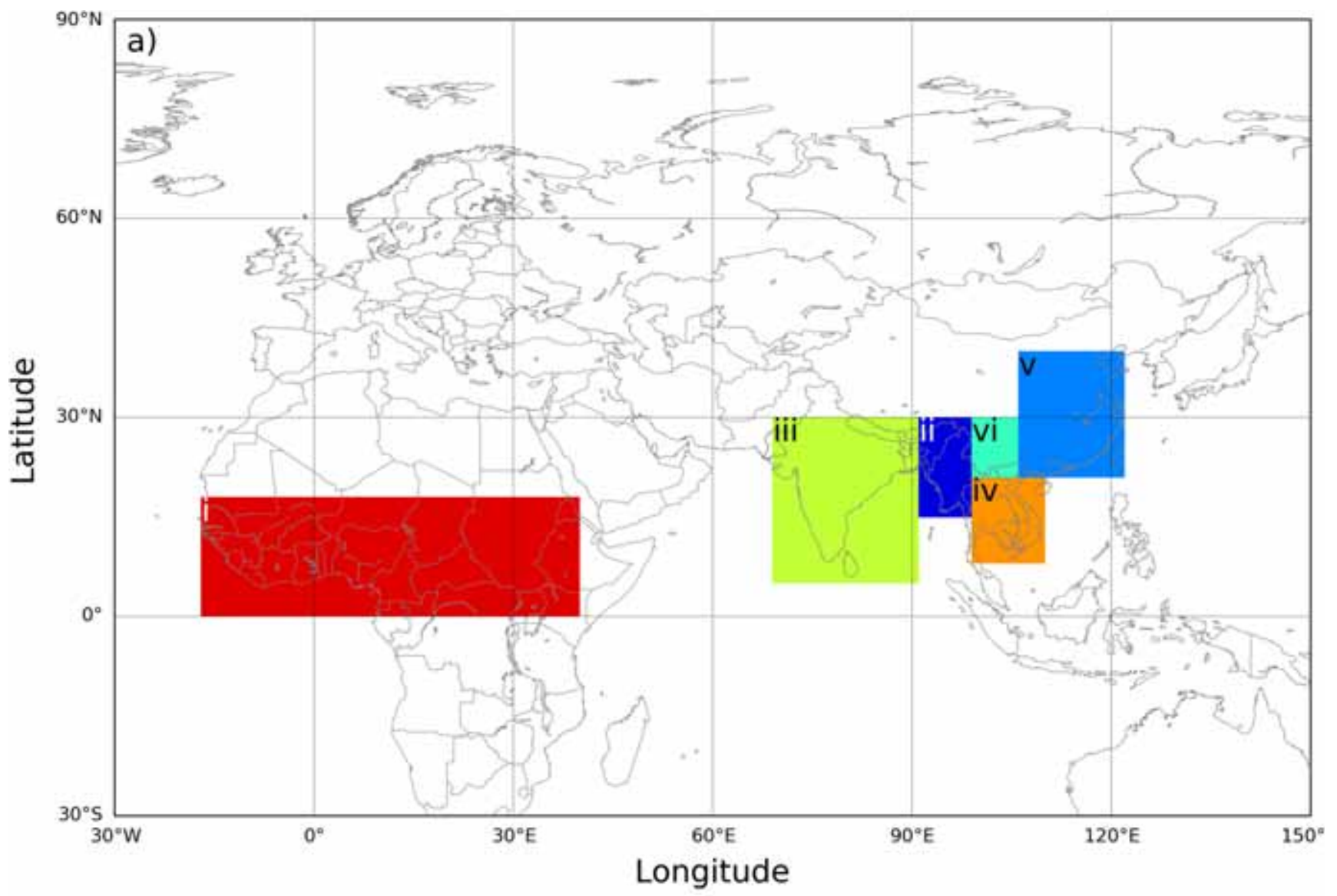

b) $15^{\text {th }}$ April 2013
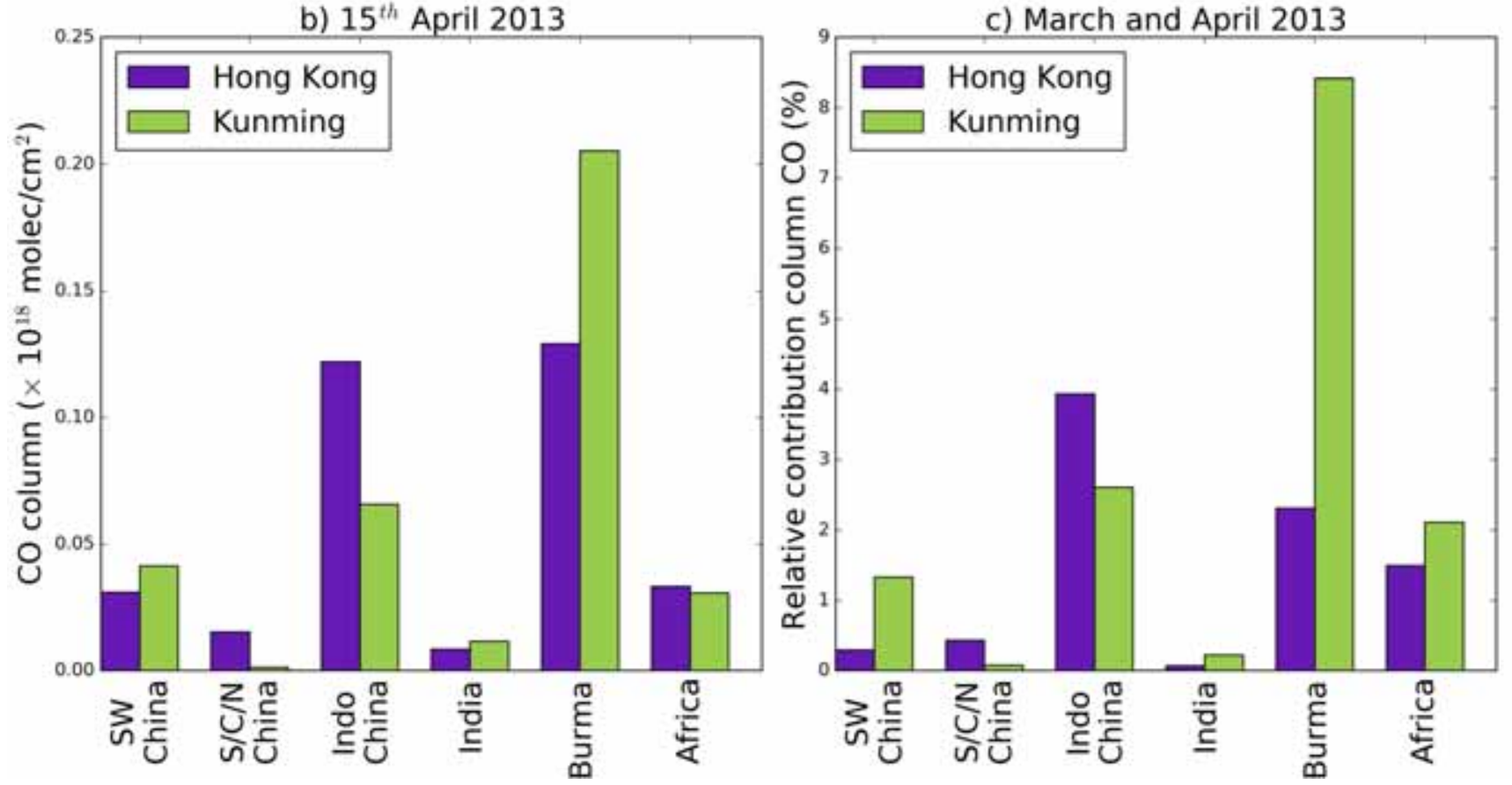

Fig. 3 a Classification of source regions in the GEOS-Chem simulations (i) Africa, (ii) Burma (iii), India (iv), Indochina (Thailand, Vietnam, Laos) biomass burning contributions to local CO concentrations on 15 April 2013. c Relative biomass burning contributions to local CO concentrations, March-April 2013 averages 

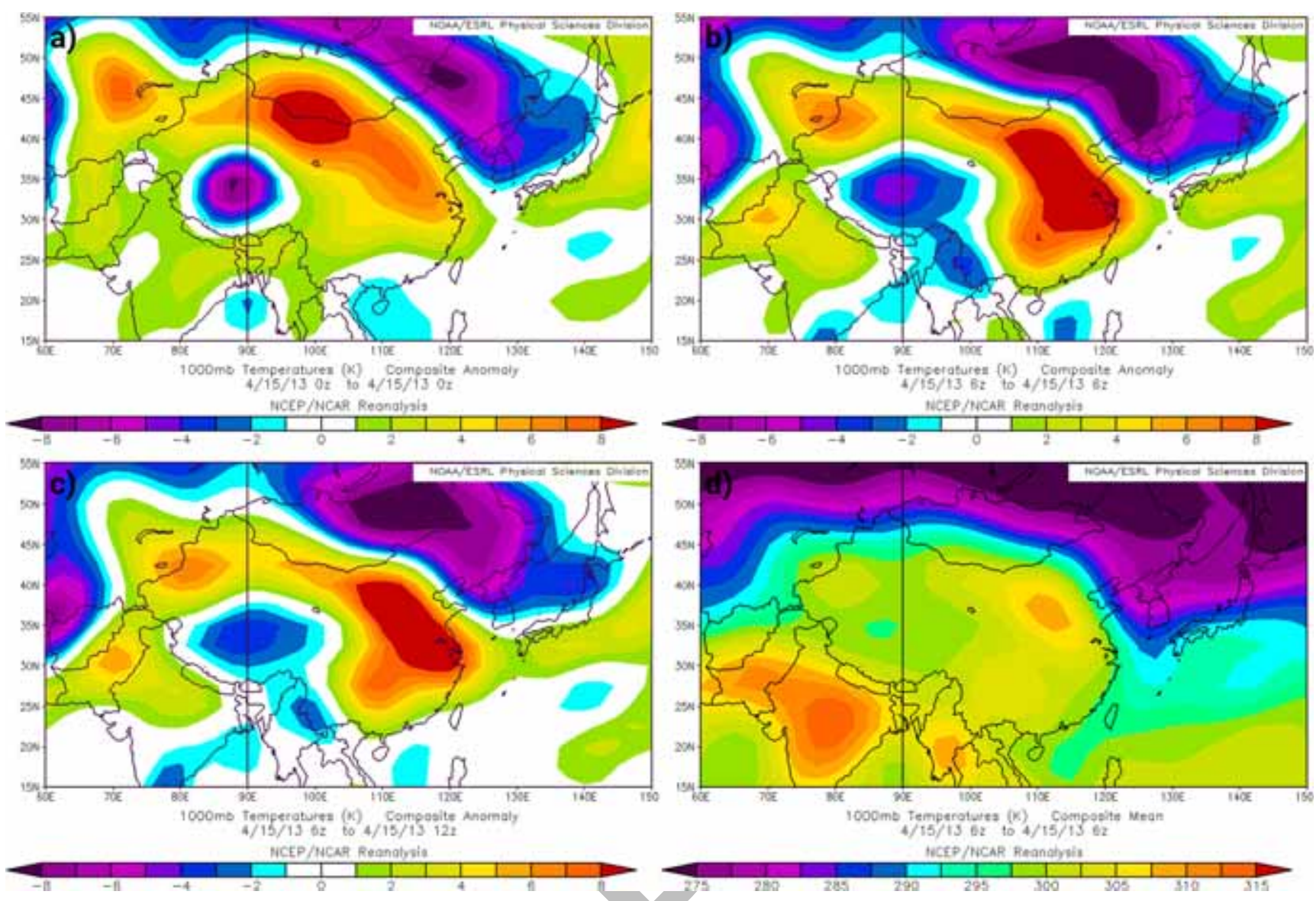

Fig. 4 Air temperature anomaly 15 April 2013 0Z (a), 06Z (b), 06Z-12Z (c), and (d) temperature mean 15 April 2013 6Z

\section{Other meteorological anomalies}

Climatic anomalies do not solely explain the factors controlling ozone formation. High solar ultraviolet radiation part of shortwave radiation, during daylight hours, for instance, will exert influence as the driving force in photochemical ozone formation. It was strong on the episode day, and indeed, the daily global solar radiation was $22.61 \mathrm{MJ} / \mathrm{m}^{2}$ on 15 April 2013. However, on another occasion when other factors weighed more heavily, a higher daily global solar radiation of $27.49 \mathrm{MJ} / \mathrm{m}^{2}$ on 14 April $2015 \mathrm{did}$ not lead to another episode.

Climate change has modified weather patterns. Typically stable atmospheric conditions exist during light wind and fair sky conditions. The stagnant air mass above the surface is restrictive to convective mixing and ozone dispersion. Specifically, atmospheric stability limits vertical turbulence. Hafez and Almazroui (2014) found that the atmosphere had become more stable as global warming increased the anomaly of global annual geopotential height (Fig. 5a, 0Z). Horton et al. (2014) suggested that global warming-driven stagnation had caused the buildup of pollutants. Their climate model simulations to quantify stagnation occurrence and persistence suggested that by the end of the century, more than half of the world's population would be exposed to increasingly stagnant conditions, with the tropics and subtropics bearing the brunt of air quality degradation, and this would deteriorate further in the latter part of the century. The air temperature anomaly (Fig. 4b) almost coincided with the geopotential height anomaly (Fig. 5b), which is worrying. The stability and the subadiabatic lapse rate on the episodic day are further illustrated by a tephigram showing vertical sounding data of up to $450 \mathrm{hPa}$ on 15 April 2013 (Fig. 5c). The red line shows the vertical profile of observed temperature. The diagram incorporates the environmental lapse rate, temperature, dew point, and wind barb data. It was generated through HKUST's Realtime Display.

Other factors may cause weather patterns that are favorable for accelerated chemistry and trapping of ozone. Clearly, when ample sunshine prevails (Fig. 5d), a small cloud fraction like that on the episode day would increase the UV radiation and therefore the photochemistry. During the day, the cloud fraction was as low as 0 to 0.125 (Fig. 5e). It was zero for most of South China. On the other hand, while higher wind speeds 

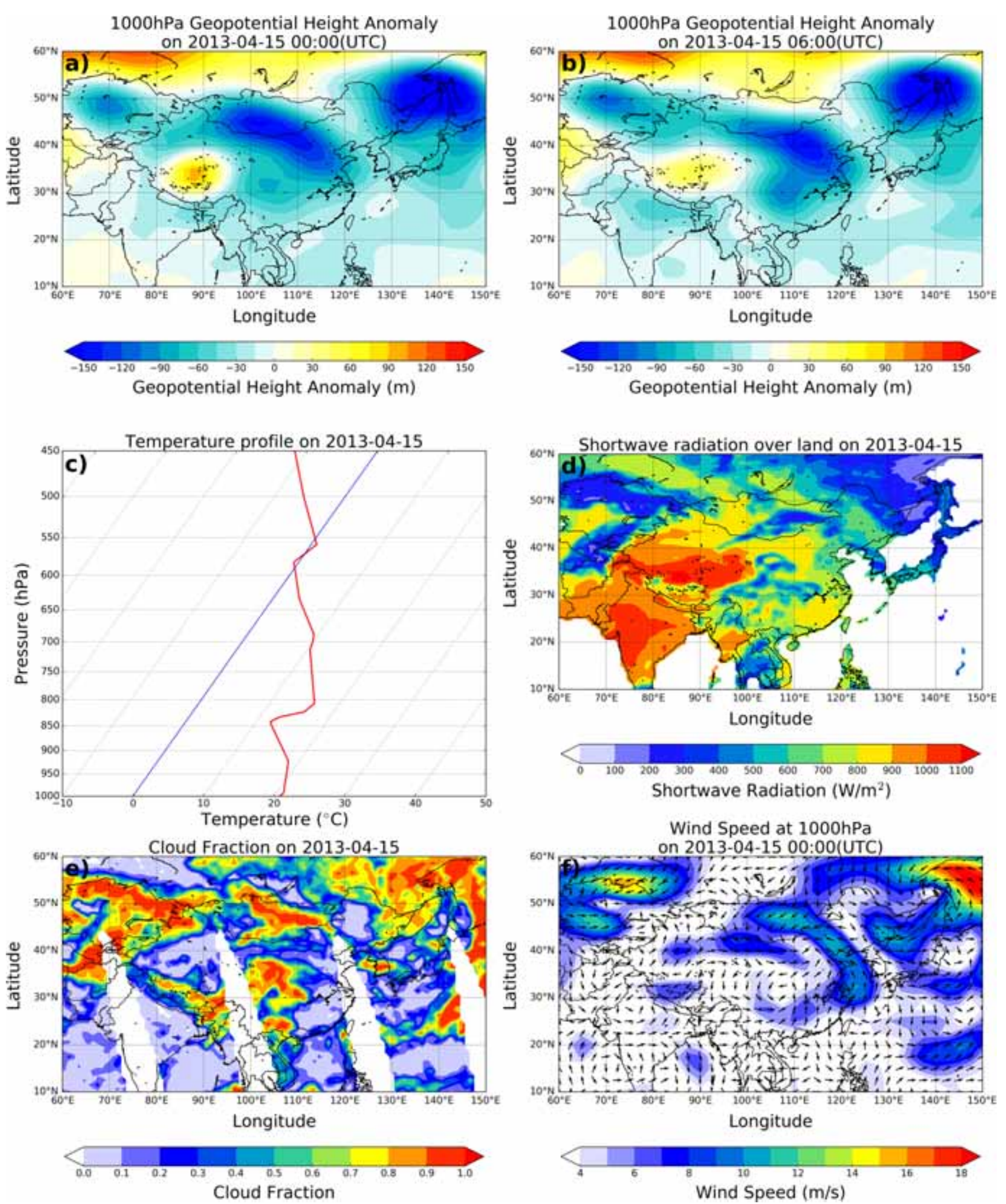

Fig. 5 1000-mb geopotential height (m) composite anomaly on 15 April 2013 0Z (a) and 6Z (b). (c) Vertical sounding 0Z. (d) Incident shortwave radiation land, time-average hourly, 6Z. (e) Total cloud area fraction $6 \mathrm{Z}$. (f) $1000-\mathrm{mb}$ winds $(\mathrm{m} / \mathrm{s})$ composite anomaly $6 \mathrm{Z}$

tend to dilute pollutants, low wind speed conditions will suppress vertical or horizontal mixing, as thermal inversions or subsidence layers may be present, and limit dispersion. Zero wind or calm $(<1 \mathrm{~m} / \mathrm{s})$ noticeably prevail over parts of the 
region. As observed in Fig. 5f, the affected areas largely have winds composite anomaly of less than $4 \mathrm{~m} / \mathrm{s}$.

\section{The ozone problem is widespread}

We use the statistical correlation of ozone (ozone total column) with surface temperature to show the spread of ozone across China. This correlation denotes the sensitivity of ozone to temperature which has previously revealed ozone blackspots of the PRD and the Sichuan basin in Southwest China (Lee et al. 2014). The inter-comparison between satellite ozone data and surface ozone data (S4a) lends support to this method which conveniently tracks the temporal and spatial changes of ozone distribution.

Regrettably, data before August 2002 NASA's AIRS was not available. However, valuable insights can be gained by going through the past images plotted. To say the least, ozone had expanded to North China as early as April 2003 (S4b), then 2005 to 2012, and in March of all years. In 2010, the correlation coefficient was over 0.8 in part of Southern China, implying very high ozone levels and air temperature at surface. This growth was found even in winter. Ozone had actually spread to areas originally largely unaffected. On the other hand, since ozone's sensitivity to temperature is even more enhanced in autumn than in spring, the expansion was particularly serious in the autumns of 2011, 2013 to 2015.

Undeniably, Southwest, Central, and North China were all seeing an increase in the scale of the problem, which has been developing in parallel with the levels of fine particulates (Zhang and Cao 2015). Toxic haze had almost become a fixture in a vast section of China. This phenomenon matched with the $3.4 \%$ increase from 2014 to 2015 in the annual mean concentration of ozone. It was declared the most serious pollutant in China from 2013 to 2015 (Clean Air Asia 2016) especially in the Yangtze River Delta region. With the help of jet streams, pollution moye across China and the Pacific to North America. In the face of a deepening transboundary crisis aggravated by extreme heat, mitigation strategies are necessary.

\section{Summary and conclusions}

Ozone has seen a dramatic rise in southern China, even more so in Southwest China. While episodes in summer and autumn have become commonplace, their occurrence during spring has not been reported or investigated. In this paper, we present a detailed analysis of a multi-day regional springtime ozone episode in Hong Kong and outbreaks in South and Southwest China. Springtime warming is evident in the retrospective MERRA time series dating back to 1980. Climatic/ meteorological factors including air temperature $(\mathrm{K})$ composite anomalies and temperature stability have crucial roles. The sources of precursors and ozone are characterized by GEOSChem simulations, with their contributions quantified.

The worst springtime ozone episode in Hong Kong up until 2018 occurred on 15 April 2013, measuring a peak ozone concentration of $293 \mu \mathrm{g} \mathrm{m}^{-3}$. The photochemical episodes in Kunming (Yunnan), as represented by $\mathrm{CO}$ level (in $\mathrm{CO}$ column, $10^{18} \mathrm{molec} / \mathrm{cm}^{2}$ ), were more severe than in Hong Kong, with the worst pollution measured on 12th-13th, about 2 days earlier. Meanwhile, elevated ozone was found in Guangzhou on the 14th. This close succession of outbreaks from west to east suggests a common eastward transport of ozone and precursors.

Drawing from the GEOS-Chem simulation results for the 15 April episode, Indochina contributed the most to the local $\mathrm{CO}$, followed by Africa and South China. In terms of total column CO $\left(10^{18} \mathrm{molec} / \mathrm{cm}^{2}\right), 0.14$ units can be attributed to Thailand, Vietnam, and Laos. The FIRMS fire maps and backward trajectories distinctly isolated the influence from South China brought in by the northeast monsoon. The precursors from Indochina, Southwest China, and Africa were carried by powerful westerlies up to about $5 \mathrm{~km}$ passing over the region, reaching Hong Kong and Guangzhou. The influence on Kunming was overwhelmingly from Burma, aside from sources similar to those affecting Hong Kong. The total column $\mathrm{CO}\left(10^{18} \mathrm{molec} / \mathrm{cm}^{2}\right)$ to Kunming attributable to Burma is 0.21 units on the 15 th.

The other controlling factor on episodic ozone is air temperature $(\mathrm{K})$ presented as air temperature composite anomalies. The intensive positive temperature anomaly was first observed to extend southeastward across China on 15 April 2013 0Z (0800 local time), covering South China at 6Z (1400) in the early afternoon, while that part affecting Indochina at $0 \mathrm{Z}$ had mainly receded. At $6 Z$, most of South China exhibited an anomaly of about $4^{\circ} \mathrm{K}$. However, the dispersion of ozone was hindered owing to the stable air mass above the surface, with zero, calm, or low wind. This atmospheric stability, represented by the global annual geopotential height anomaly, is shown to aggravate as global warming increases.

Correlation maps denoting the sensitivity of ozone to temperature indicate that ozone had actually spread to North China in 2003 or well before that in April, March, and even the winter months. Satellite images lend support to the fact that the precursors and ozone were carried across the oceans by high speed westerlies and jet streams. This widening ozone crisis in spring which is aggravated by extreme heat should be addressed by country-wide efforts in China in collaboration with Asian and other countries.

Acknowledgments We thank the Hong Kong Observatory and the Environmental Protection Department of Hong Kong for the provision of meteorological and air quality data, and the Hong Kong University of Science and Technology for the vertical sounding data. The authors would also like to thank the NASA Goddard Earth Sciences Data and Information Services Center (GES DISC), the NOAA Earth System 
Research Laboratory (ESRL) Air Resources Laboratory (ARL) for the provision of data and tools used in this publication.

Funding information The work described in this paper was financially supported by the Marie Curie Initial Training Network of the European Seventh Framework Programme (Grant No. 607905).

\section{References}

Anttila P, Stefanovska A, Nestorovska-Krsteska A, Grozdanovski L, Atanasov I, Golubov N, Ristevski P, Toceva M, Lappi S, Walden J (2016) Characterisation of extreme air pollution episodes in an urban valley in the Balkan Peninsula. Air Qual Atmos Health 9:129 141. https://doi.org/10.1007/s11869-015-0326-7

Bey I, Jacob DJ, Yantosca RM, Logan JA, Field BD, Fiore AM, Li Q, Liu HY, Mickley LJ, Schultz MG (2001) Global modeling of tropospheric chemistry with assimilated meteorology: model description and evaluation. J Geophys Res Atmos 106(D19):23073-23095

Bloomer BJ, Stehr JW, Piety CA, Salawitch RJ, Dickerson RR (2009) Observed relationships of ozone air pollution with temperature and emissions. Geophys Res Lett 36(9):L09803. https://doi.org/10. 1029/2009GL037308

Bond TC, Bhardwaj E, Dong R, Jogani R, Jung S, Roden C, Streets DG, Trautmann NM (2007) Historical emissions of black and organic carbon aerosol from energy-related combustion. Glob Biogeochem Cycles 21(2):1850-2000. https://doi.org/10.1029/2006GB002840

Chan KL, Chan KL (2017) Aerosol optical depths and their contributing sources in Taiwan. Atmos Environ 148:364-375. https://doi.org/10. 1016/j.atmosenv.2016.11.011

Chan CY, Chan LY, Chang WL, Zheng YG, Cui H, Zheng XD, Qin Y, Li YS (2003a) Characteristics of a tropospheric ozone profile and implications for the origin of ozone over subtropical China in the spring of 2001. J Geophys Res 108(D20):8800. https://doi.org/10. 1029/2003JD003427

Chan CY, Chan LY, Harris JM, Oltmans SJ, Blake DR, Qin Y, Zheng YG, Zheng XD (2003b) Characteristics of biomass burning emission sources, transport, and chemical speciation in enhanced springtime tropospheric ozone profile oyer Hong Kong. J Geophys Res Atmos 108(D1):ACH 3-1-ACH 3-13. https://doi.org/10.1029/ 2001JD001555

Chan HS, Kok MH, Lee TC (2012) Temperature trends in Hong Kong from a seasonal perspective. Clim Res 55(1):53-63. https://doi.org/ $10.3354 / \mathrm{cr} 01133$

China National Environmental Monitoring Centre. Monthly air quality report of 74 cities. Technical Report 2016

Clean Air Asia, China Air 2016, Air pollution prevention and control progress in Chinese cities. Technical Report, 2016

Collins WJ, Derwent RG, Garnier B, Johnson CE, Sanderson MG, Stevenson DS (2003) Effect of stratosphere-troposphere exchange on the future tropospheric ozone trend. J Geophys Res Atmos 108(D12). https://doi.org/10.1029/2002JD002617

Diehl T, Heil A, Chin M, Pan X, Streets D, Schultz M, Kinne S (2012) Anthropogenic, biomass burning, and volcanic emissions of black carbon, organic carbon, and $\mathrm{SO}_{2}$ from 1980 to 2010 for hindcast model experiments. Atmos Chem Phys Discuss 12:24895-24954

Ding A, Wang T, Zhao M, Wang T, Li Z (2004) Simulation of sea-land breezes and discussion of their implications on the transport of air pollution during a multi-day ozone episode in the Pearl River Delta of China. Atmos Environ 38:6737-6750. https://doi.org/10.1016/j. atmosenv.2004.09.017
Eastham SD, Weisenstein DK, Barrett SRH (2014) Development and evaluation of the unified tropospheric-stratospheric chemistry extension (UCX) for the global chemistry transport model GEOS-Chem. Atmos Environ 89:52-63. https://doi.org/10.1016/j.atmosenv.2014. 02.001

EDGAR4.2 (2011) Emission Database for Global Atmospheric Research (EDGAR), Release Version 4.2. Technical Report MSU-CSE-00-2, European Commission, Joint Research Centre (JRC)/Netherlands Environmental Assessment Agency (PBL)

Gelaro R, McCarty W, Suárez MJ, Todling R, Molod A, Takacs L, Randles CA, Darmenov A, Bosilovich MG, Reichle R, Wargan K, Coy L, Cullather R, Draper C, Akella S, Buchard V, Conaty A, da Silva AM, Gu W, Kim G-K, Koster R, Lucchesi R, Merkova D, Nielsen JE, Partyka G, Pawson S, Putman W, Rienecker M, Schubert SD, Sienkiewicz M, Zhao B (2017) The modern-era retrospective analysis for research and applications, version 2 (MERRA-2). J Clim 30:5419 5454. https://doi.org/10.1175/JCLI-D-16-0758.1

Giglio L, Randerson JT, van der Werf GR (2013) Analysis of daily, monthly, and annual burned area using the fourth-generation global fire emissions database (GFED4)(2013). J Geophys Res: Biogeosci, 118(1), 317-328. https://doi.org/10.1002/jgrg.20042

Giglio L, Schroeder W, Justice CO (2016) The collection 6 MODIS active fire detection algorithm and fire products. Remote Sens Environ 178:31-41. https://doi.org/10.1016/j. rse.2016.02.054

GPEMC-Hong Kong-Macau Pearl River Delta regional air quality monitoring network: a report of monitoring results in 2014. Technical Report 2015

Guangdong Provincial Environmental Monitoring Centre, Guangdong (GPEMC) Hong Kong-Macau Pearl River Delta regional air quality monitoring network: a report of monitoring results in 2013. Technical Report 2014

Guenther AB, Jiang X, Heald CL, Sakulyanontvittaya T, Duhl T, Emmons LK, Wang X (2012) The model of emissions of gases and aerosols from nature version 2.1 (MEGAN2.1): an extended and updated framework for modeling biogenic emissions. Geosci Model Dev 5(6):1471-1492.W. https://doi.org/10.5194/gmd-51471-2012

Hafez YY, Almazroui M (2014) Recent study of anomaly of global annual geopotential height and global warming. Atmos Clim Sci 4: 347-357. https://doi.org/10.4236/acs.2014.43035

Hong Kong Government (2015) Press release related to the release of the reports. Air quality in Hong Kong 2014 and the Pearl River Delta regional air quality monitoring report

Horton DE, Skinner CB, Singh D, Diffenbaugh NS (2014) Occurrence and persistence of future atmospheric stagnation events. Nat Clim Chang 4:698-703. https://doi.org/10.1038/nclimate2272

Intergovernmental Panel on Climate Change Data Distribution Centre http://www.ipcc-data.org/guidelines/pages/glossary/glossary_fg. $\mathrm{html}$

Justice CO, Giglio L, Korontzi S, Owens J, Morisette J, Roy D, Descloitres J, Alleaume S, Petitcolin F, Kaufman YJ (2002) The MODIS fire products. Remote Sens Environ 83:244-262. https:// doi.org/10.1016/S0034-4257(02)00076-7

Lee YC, Wenig M, Zhang Z, Sugimoto N, Larko D, Diehl T (2012) Dust episodes in Hong Kong (South China) and their relationship with the Sharav and Mongolian cyclones and jet streams. Air Qual Atmos Health 5(4):413-424. https://doi.org/10.1007/s11869-011-0134-7

Lee YC, Lam YF, Kuhlmann G, Wenig MO, Chan KL, Hartl A, Ning Z (2013) An integrated approach to identify the biomass burning sources contributing to black carbon episodes in Hong Kong. Atmos Environ 80:478-487. https://doi.org/10.1016/j.atmosenv. 2013.08.030

Lee YC, Shindell DT, Faluvegi G, Wenig M, Lam YF, Ning Z, Hao S, Lai CS (2014) Increase of ozone concentrations, its temperature 
sensitivity and the precursor factor in South China. Tellus B 66 . https://doi.org/10.3402/tellusb.v66.23455

Li M, Zhang Q, Kurokawa JI, Woo JH, He K, Lu Z, Ohara T, Song Y, Streets DG, Carmichael GR, Cheng Y, Hong C, Huo H, Jiang X, Kang S, Liu F, Su H, Zheng B (2017) MIX: a mosaic Asian anthropogenic emission inventory under the international collaboration framework of the MICS-Asia and HTAP. Atmos Chem Phys 17: 935-963. https://doi.org/10.5194/acp-17-935-2017

Lollar BS, Holland HD, Turekian KK (2004) Treatise on geochemistry. Volume 9: Environmental geochemistry. Elsevier, Amsterdam

Ministry of Science and Technology, PRC (2015) Third National Assessment Report on Climate Change: a study by the Ministry of Science and Technology, China Meteorological Administration, Chinese Academy of Sciences and the Chinese Academy of Engineering. Presented at the United Nations Climate Change Conference, Paris, November 2015

NASA Goddard homepage for tropospheric ozone. https://acd-ext.gsfc. nasa.gov/Data_services/cloud_slice/. Retrieved 2017

NASA, GSFC, Ozone hole watch, 2013 (version)

NASA Jet Propulsion Laboratory (n.d.-a) Tropospheric emission spectrometer (TES): intercontinental transport of pollutants. https://tes. jpl.nasa.gov/mission/PollnTransport/

NASA Jet Propulsion Laboratory (n.d.-b) Tropospheric emission spectrometer (TES): biomass burning. https://tes.jpl.nasa.gov/mission/ biomassburning/

NOAA National Centers for Environmental Information, State of the climate: global climate report - annual 2016, Published online January 2017a, retrieved on July 17, 2017

NOAA National Centers for Environmental Information, Climate monitoring 2017b: anomalies vs. temperature

Petrenko VV, Martinerie P, Novelli P, Etheridge DM, Levin I, Wang Z, Blunier T, Chappellaz J, Kaiser J, Lang P, Steele LP, Hammer S, Mak J, Langenfelds RL, Schwander J, Severinghaus JP, Witrant E, Petron G, Battle MO, Forster G, Sturges WT, Lamarque J-F, Steffen K, White JWC (2013) A 60 yr record of atmospheric carbon monoxide reconstructed from Greenland firn air. Atmos Chem Phys 13: 7567-7585. https://doi.org/10.5194/acp-13-7567-2013
Stein A, Draxler R, Rolph G, Stunder B, Cohen M, Ngan F (2015) NOAAs HYSPLIT atmospheric transport and dispersion modeling system. Bull Am Meteorol Soc 96(12):2059-2077. https://doi.org/ 10.1175/BAMS-D-14-00110.1

Suarez MJ, et al (2005) Documentation and validation of the Goddard Earth Observing System (GEOS) data assimilation system, version 4. 26

Té Y, Jeseck P, Franco B, Mahieu E, Jones N, Paton-Walsh C, Griffith DWT, Buchholz RR, Hadji-Lazaro J, Hurtmans D, Janssen C (2016) Seasonal variability of surface and column carbon monoxide over the megacity Paris, high-altitude Jungfraujoch and Southern Hemispheric Wollongong stations. Atmos Chem Phys 16(17): 10911-10925. https://doi.org/10.5194/acp-16-10911-2016

USEPA (2016) NAAQS table. Technical report; United States Environmental Protection Agency

USEPA Quality assurance handbook for air pollution measurement systems volume II : ambient air quality monitoring program. EPA-454/ B-17-001 January 2017

Zhang YL, Cao F (2015) Fine particulate matter $\left(\mathrm{PM}_{2.5}\right)$ in China at a city level. Sci Rep 5:14884. https://doi.org/10.1038/srep14884

Zhu J, Xia X, Che H, Wang J, Zhang J, Duan Y (2016) Study of aerosol optical properties at Kunming in Southwest China and long-range transport of biomass burning aerosols from North Burma. Atmos Res 169:237-247. https://doi.org/10.1016/j.atmosres.2015.10.0

Ziemke JR, Chandra S, Duncan BN, Froidevaux L, Bhartia PK, Levelt PF, Waters JW (2006) Tropospheric ozone determined from Aura OMI and MLS: evaluation of measurements and comparison with the global modeling initiative's chemical transport model. J Geophys Res Atmos 111(D19). https://doi.org/10.1029/ 2006JD007089

Publisher's note Springer Nature remains neutral with regard to jurisdictional claims in published maps and institutional affiliations.
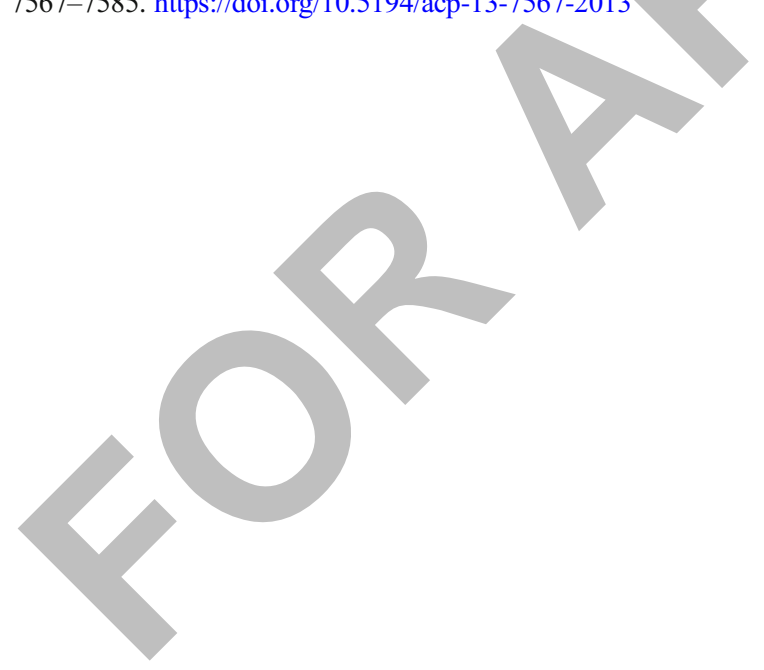